D3R and D2R. On comparing the structure with that of a molecule that blocks only D3R, they found that D3R has a second binding site not present on D2R.

Science 330, 1091-1095 (2010)

\section{DEVELOPMENTAL BIOLOGY}

\section{Blood-vessel cells turn to bone}

In the rare disease fibrodysplasia ossificans progressiva (FOP), a mutation in the Alk2 gene results in the formation of bone in soft tissues. Now researchers show that the bone cells derive from others that form the inner lining of blood vessels, called endothelial cells.

These become stem-like cells before re-differentiating into bone. This process could be important in normal tissue repair, suggest Damian Medici at Harvard Medical School and Bjorn Olsen at the Harvard School of Dental Medicine, both in Boston, Massachusetts, and their colleagues.

The team found that cells from bony lesions in patients with FOP expressed marker proteins specific for endothelium. And when mutant $A l k 2$ was introduced into normal human endothelial cells, it conferred characteristics of mesenchymal stem cells. When cultured in appropriate conditions, the endothelial-derived 'stem cells' transformed into bone, cartilage and fat cells.

Nature Med. doi:10.1038/ nm.2252 (2010)

\section{GENE THERAPY}

\section{Small RNAs aid}

\section{cell transplants}

With the help of small RNA molecules called microRNAs, a metabolic and neurodegenerative disorder might be treated using gene therapy.

Patients with Krabbe's disease lack a functioning version of an enzyme called GALC. Transplants of genetically engineered blood stem cells that later develop into white blood cells could potentially deliver a corrected version of GALC. But expressing the protein in the stem cells kills them.

Alessandra Biffi and Luigi Naldini of the San Raffaele Scientific Institute in Milan, Italy, and their colleagues identified gene-silencing microRNAs that are expressed in the stem cells, but not in the mature white blood cells. The researchers then modified the stem cells so that GALC expression was suppressed by a microRNA in the stem cells but not in the white blood cells. As the cells developed, they were able to deliver GALC to diseased tissues in a mouse model of Krabbe's disease.

Science Transl. Med. doi:10.1126/ scitransImed.3001522 (2010)

\section{MATERIALS SCIENCE}

\section{Stopping ice} before it forms

Ice accumulation on aircraft and other structures can be dangerous, but de-icing procedures are expensive or environmentally unfriendly. Joanna Aizenberg at Harvard University in Cambridge, Massachusetts, and her collaborators show how ice could be prevented from forming on cold surfaces.

Combining theoretical predictions with experiments, the authors fabricated a silicon surface with honeycomb-like microstructures and coated it with a water-repellent polymer film. There was minimal contact time and heat transfer between the surface and a falling water droplet,
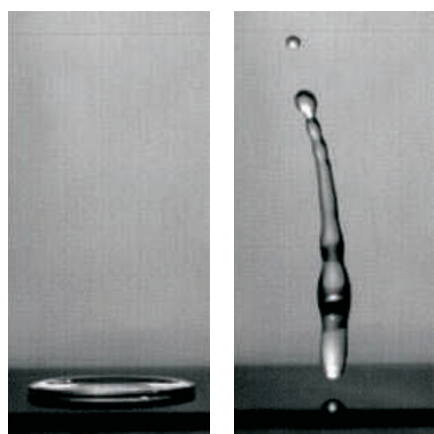

COMMUNITY CHOICE

The most viewed papers in science

\title{
Hills emerge as glaciers retreat
}

\section{Q highly read \\ on geology. gsapubs.org in October}

Most drumlins - small, rounded hills were formed under melting Pleistocene ice sheets. But the recent retreat of the Múlajökull glacier in Hofsjökull, Iceland, has uncovered the only known active drumlin field created during modern times.

Mark Johnson of the University of Gothenburg, Sweden and his colleagues identified more than 50 drumlins in this field and studied their sediment layers. Some theories posit that drumlins are carved out from the sediment by a rush of glacial meltwater. By contrast, the new observations suggest that drumlins form by sediment being repeatedly deposited and then eroded underneath the glacier over successive rounds of glacier growth and retreat. Geology doi:10.1130/G31371.1 (2010)

such that after it made contact (pictured, left), the droplet fully retracted (right) before it could freeze. This prevented ice formation in temperatures down to about $-25^{\circ} \mathrm{C}$.

ACS Nano doi:10.1021/ nn102557p (2010)

\section{ZOOLOGY \\ Fish cocoons block biting bugs}

The mucus cocoons in which some fish sleep seem to protect them from attacks by parasitic invertebrates.

Alexandra Grutter at the University of Queensland in Brisbane, Australia, and her colleagues placed coralreef parrotfish (Chlorurus sordidus) in bins of water with parasitic gnathiid isopods overnight. They found that only $10 \%$ of fish in cocoons were attacked by the parasites, compared with $94.4 \%$ of fish that had been teased out of their shelters.

Secreting the mucus to prevent parasite attacks - a mechanism thought to be unique to these fish - costs around $2.5 \%$ of a fish's daily energy budget, the researchers calculate.

Biol. Lett. doi:10.1098/

rsbl.2010.0916 (2010)

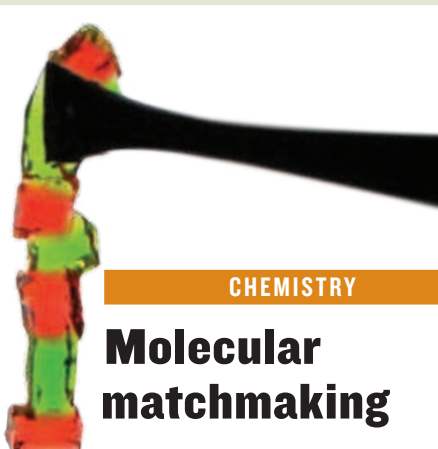

Structures up to centimetres long have been created by the self-assembly of gel particles that 'recognize' each other at the molecular level. Such molecular recognition has previously been used to selfassemble molecules at the microscopic scale. Akira Harada of Osaka University in Japan and his colleagues prepared acrylamide-based 'host' gels bearing cyclodextrin rings, and other gels with smaller 'guest' hydrocarbons. The rings and the guest molecules bound to each other, allowing small pieces of gel to selfassemble in specific ways (pictured).

Nature Chem. doi:10.1038/ nchem.893 (2010)

\section{$\rightarrow$ NATURE.COM}

For the latest research published by Naturevisit:

www.nature,com/latestresearch 